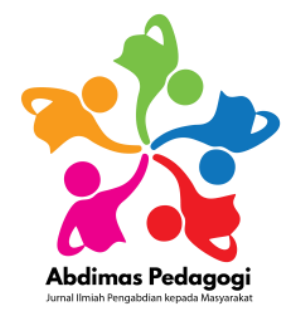

Abdimas Pedagogi: Jurnal Ilmiah Pengabdian kepada Masyarakat

Vol 2, No. 3, 2019, hlm.122—134

ISSN 2615-3122 (online)

ISSN 2548-6683 (print)

\title{
PELATIHAN KETERAMPILAN MENGANYAM UNTUK MENINGKATKAN KUALITAS PEMBELAJARAN SENIRUPA BAGI GURU SEKOLAH DASAR
}

\author{
A. Badawi, Sumanto*, dan Murtiningsih \\ Jurusan KSDP, Fakultas Ilmu Pendidikan, Universitas Negeri Malang, Indonesia \\ Jalan Semarang no. 5 Malang \\ *e-mail: sumantomunginan@gmail.com
}

\begin{abstract}
This art and culture training and workshop aims to practice the skills: (1) making woven from asturo paper to improve the quality of visual art learning in elementary schools. Training methods by providing individual practice guidance to weaving skills directly to 24 elementary school teachers. Outcomes (1) Non-physical for elementary school teachers in Ngantang sub-district are very interested in getting art-crafted training, and are willing to disseminate knowledge and skills to other teachers in their assignments. (2) individual trainees are skilled at making (a) woven fish, flying birds, stars, baskets (baskets), and woven ribbons in the shape of frames.
\end{abstract}

Keywords: skills in making webbing; asturo paper; elementary School teacher

\begin{abstract}
Abstrak: Pelatihan seni budaya dan prakarya ini bertujuan melatih keterampilan: (1) membuat anyaman dari kertas asturo untuk meningkatkan kualitas pembelajaran senirupa di SD. Metode pelatihan dengan memberikan bimbingan praktek individu keterampilan menganyam secara langsung kepada 24 guru SD. Hasil (1) non-fisik bagi guru-guru SD di kecamatan Ngantang sangat berminat mendapat pelatihan senirupa-prakarya, dan bersedia untuk menyebarluaskan pengetahuan dan keterampilan kepada guru lain di tempat tugasnya. (2) peserta pelatihan secara individu terampil membuat (a) anyaman bentuk ikan, burung terbang, bintang, keranjang (besek), dan anyaman pita bentuk pigura.
\end{abstract}

Kata kunci: keterampilan membuat anyaman; kertas asturo; guru SD

\section{PENDAHULUAN}

Kecamatan Ngantang merupakan salah satu kecamatan yang ada di Kabupaten Malang. Secara geografis kecamatan Ngantang terletak diantara kecamatan Kasembon, dan Pujon. Di kecamatan Ngantang Kabupaten Malang terdapat lembaga pendidikan dasar (Sekolah Dasar) Negeri yang tersebar di setiap Desanya. Gugus 1 di kecamatan Ngantang yang menjadi kelompok sasaran Abdimas tahun 2019 ini memiliki 7 lembaga pendidikan SD Negeri. Berdasarkan data 
kualifikasi guru kelas menunjukkan bahwa tingkat pendidikan Guru SD di gugus 1 kecamatan Ngantang Malang bervariasi, ada sebagian besar lulusan sarjana pendidikan guru (PGSD), dan ada yang lulusan S1 di luar kependidikan guru kelas. Dilihat dari acuan kurikulum yang digunakan dalam pembelajaran di kelas sudah menggunakan Kurikulum 2013.

Guru kelas SD sebagai tenaga pendidik profesional yang berperan sebagai fasilitator dalam pembelajaran dituntut kreativitasnya untuk menggali potensi sumber belajar, materi pembelajaran, dan media pembelajaran yang ada di lingkungannya agar dapat membelajarkan muridnya secara berkwalitas. Menjadi fasilitator yang baik guru SD diharapkan dapat membekali diri dengan wawasan dan keterampilan kreatif mengembangkan materi pembelajaran yang berorientasi pada aktivitas kreatif anak. Salah satu muatan materi pelajaran yang sarat akan kemampuan kreatif guru kelas adalah pembelajaran Seni Budaya dan Prakarya (SDdP). Sesuai dengan kompetensi dasar dan indikator yang ada pada muatan SBdP aspek keterampilan (KI4) berkaitan dengan materi praktek berkarya kreatif senirupa. Diantaranya Menggambar, Mencetak, Membentuk, Aplikasi mosaik, montase, kolase, jenis berkarya Prakarya (kerajinan tangan) dan lainnya.

Kondisi yang ada di lapangan (di kelas) para guru merasa kurang memiliki kemampuan terampil kreatif untuk membelajarkan kemampuan berkarya kreatif pada siswa di kelasnnya. Kondisi yang demikian disebabkan para guru kurang memahami dan kurang terampil dalam mempraktekkan beragam karya senirupa. Seharusnya guru memiliki kemampuan kreativitas menganyam, sehingga mampu mengembangkan pembelajaran seni di kelas dengan baik dan menarik bagi siswa. Dampak yang dilihat di kelas yaitu pembelajaran SBdP masih kurang berjalan dengan baik. Dalam konteks ini guru sebagai fasilitator masih diperlukan atau dibutuhkan bekal pengetahuan dan keterampilan membelajarkan senirupa dengan lebih kreatif agar dapat menjalankan perannya dengan baik. Tanpa bekal yang cukup guru SD tidak akan dapat meningkatkan kualitas pembelajaran SBdP dalam melaksanakan tugasnya.

Dari hasil observasi awal dan wawancara dengan beberapa guru dan kepala SD serta pengurus Gugus 1 yang ada di wilayah kecamatan Ngantang menunjukkan bahwa para guru SD pada umumnya mengalami kesulitan dalam meningkatkan kwalitas dan efektivitas pembelajaran SBdP di SD nya masing-masing. Keadaan ini disebabkan kurangnya sarana dan prasarana yang dapat menunjang keaktifan dan kesenangan murid dalam belajar juga karena para guru belum memiliki wawasan dan keterampilan yang memadai untuk membuat berbagai karya kreatif senirupa yang menyenangkan bagi anak. Kreativitas guru dalam keterbatasan mutlak dibutuhkan.

Berdasarkan hasil analisis situasi tersebut maka dilakukan kegiatan pengabdian kepada masyarakat tentang "Pelatihan Berkarya Kreatif Senirupa untuk meningkatkan kwalitas pembelajaran SBdP bagi Guru-guru SD di Kecamatan Ngantang Kabupaten Malang". Keterampilan kreatif berkarya senirupa yang dilatihkan secara teknologi tidak terlalu sulit, namun diperlukan adanya kepekaan rasa keindahan dan kecermatan dalam mengobahan bahan (material) senirupa untuk dikreasi menjadi karya visual yang bernilai estetis sebagai benda hias atau benda terapan. Karya gambar merupakan hasil pikiran, keinginan, gagasan dan perasaan mahasiswa terhadap lingkungan sekitar sebagai refleksi terhadap bentuk maupun dorongan emosi terhadap lingkungannya (Pamadhi, 2008.3). Secara spesifik bentuk pelatihan berkarya kreatif tersebut yaitu menganyam model ikan, menganyam pita dibentuk bingkai foto, anyaman burung terbang, anyaman bentuk bintang, dan anyaman bentuk keranjang/besek, serta anyaman model dompet.

Dampak dari keadaan ini akan meningkatkan kwalitas proses pembelajaran senirupa-prakarya di SD pada akhirnya akan menunjang tercapainya tujuan pendidikan di daerah sasaran. Dasar pertimbangan dipilihnya lokasi daerah sasaran stategis ini dikarenakan belum pernah ada pembinaan/pelatihan bagi guru kelas dalam bidang muatan mata pelajaran SBdP. 


\section{Permasalahan Mitra}

Berdasarkan uraian latar belakang pada pendahuluan dapat digaris bawahi bahwa masalah yang mendasar yang perlu segera diatasi adalah guru-guru SD di kecamatan Ngantang dalam menjalankan tugasnya belum memiliki pengetahuan dan keterampilan berkarya kreatif senirupa sesuai kompetensi dasar dan indikator di setiap kelasnya. Secara khusus masalah tersebut dijabarkan sebagai berikut: (1) Guru-guru di Kecamatan Ngantang Malang belum memiliki wawasan yang cukup tentang konsep pembelajaran berkarya kreatif senirupa di SD. (2) Guru-guru di Kecamatan Malang belum memiliki keterampilan berkarya kreatif menganyam sederhana dengan menggunakan bahan kertas asturo, yang dapat diterapkan dalam pembelajaran SBdP di SD.

Secara operasional dari setiap permasalahan khusus yang dialami mitra tersebut dapat dijelaskan sebagai berikut. Pertama, belum dimilikinya wawasan pengetahuan berkarya kreatif senirupa dalam pendekatan pembelajaran terpadu di SD. Kedua, belum dimilikinya pengetahuan yang cukup mengenai berkarya kreatif senirupa dan prakarya bagi anak SD didasarkan pada kemampuan guru dalam memahami ruang lingkup senirupa sesuai indikator-indikator yang ada pada matapelajaran SBdP. Memahami ruang lingkup senirupa di kelas rendah SD hendaknya didukung kemampuan guru mempraktekkan setiap jenis karya senirupa dengan memilih bahan, dan media pembelajaran yang disesuaikan dengan kreasi senirupa yang dilatihkan. Ketiga, belum dimikinya kemampuan terampil membuat karya kreatif anyaman sederhana, mencetak dari bahan buatan yang memiliki kemenarikan dan kepraktisan serta ada kesesuaiannya dengan keterpaduan materi senirupa dengan mata pelajaran lainnya pada setiap subtemannya. Dengan tersediannya bahan (kertas asturo) di lingkungan sekitar dapat dimanfaatkan dalam pembuatan karya kreatif senirupa bagi guru SD. Keempat, kemampuan membuat contoh karya kreatif senirupa bagi guru SD secara umum masih perlu ditingkatkan dan dipraktekkan dalam upaya meningkatkan kualitas pembelajaran SBdP di SD khususnya kelas rendah.

Lingkup yang menjadi batasan penetapan IPTEK, yaitu: (1) Praktek berkarya kreatif anyaman model ikan, anyaman pita bentuk pigura, anyaman model bintang, anyaman burung terbang, anyaman keranjang (besek) dan dompet. (2) Peningkatan kemampuan terampil berkarya senirupa dengan memanfaatkan bahan buatan untuk meningkatkan kualitas pembelajaran SBdP di SD Kecamatan Ngantang Malang.

\section{Keterampilan Kreatif Senirupa}

Kemampuan kreatif adalah kompetensi terampil kreatif dalam menentukan sumber ide/gagasan, obyek karya senirupa sesuai media (bahan), dan teknik seni/keterampilan yang dipilihnya. Kemampuan kreatif berkarya senirupa ditandai dari tiga hal yaitu: (1) setiap jenis karya senirupa dihasilkan dari berbagai macam sumber ide yang diolah, dicipta, digubah, dan dicontoh sesuai kemapuan terampil seseorang, (2) karya senirupa dibuat dengan mempertimbangkan kaedah atau prinsip prinsip seni, yaitu kesatuan (unity), keseimbangan (balance), kesebandingan (proporsi), keselarasan (hamony), dan fokus daya tarik (aksentuasi), (3) adanya keragaman teknik penyelesaian sesuai bentuk karya yang dibuatnya. Ketiga hal di atas menguatkan kecenderungan kemampun kreatif seseorang dalam berkarya senirupa sesuai kemunculannya ciri-ciri kreatif yang dimiliki oleh seseorang. Kecenderungan ciri-ciri kreatif dalam berkarya senirupa tersebut adalah sebagai berikut.

Ciri kreatif "semangat (giat) belajar dan berusaha" untuk mendapatkan pengalaman, pengetahuan, dan keterampilan baru melalui aktivitas individual berkarya senirupa. Selama kegiatan praktek berkarya senirupa dapat diamati adanya sikap dan ekspresi dari seseorang yang menguaSDan adanya semangat belajar dan juga selalu berusaha untuk dapat membuat suatu karya 
yang bagus, indah sesuai jenis yang dibuatnya, Ciri kreatif ditandai adanya kesempatan "meluangkan waktu untuk berkarya". Selain ketersedian waktu juga berupaya mengatur waktu untuk membuat karya senirupa. Dalam kaitan ini waktu digunakan untuk berkonsentrasi mengerjakan dan menyelesaikan karya berdasarkan ide kreatifnya masing-masing. Meskipun sumber idenya sama, obyek sama, peralatan jenisnya sama, namun dimaknai dari struktur visual komposisi karya ada perbedaannya. Setiap karya seni memiliki kemenarikan dan kesan keindahan serta nilai seni yang bersifat individual.

Ciri kreatif adanya kemampuan "berekspresi dan berseni" sebagai pontensi berekspresi kreatif tentunya tidak akan membatasi diri atau menutup peluang dalam mengungkapkan ide kreatif, memilih sumber ide, dan menerapkan teknik penyelesaian setiap karya. Demikian juga kemampuan berekspresi dan berseni dapat disalurkan melalui pemilihan media dan cara-cara atau teknik seni yang dipilihnya. Ciri kreatif yaitu adanya kemampuan "sebagai penemu" dalam berkarya senirupa. Mengenai tingkat kualitas kreatif hasil temuan yang diwujudkan pada karya cetak tinggi, anyaman model ikan, membentuk model binatang, mosaik, montase, dan kolase. Kualitas kreatif mencipta, menggubah atau memodifikasi, dan tingkat yang paling rendah kadar kreatifnya yaitu mencontoh. Beraktifitas seni juga memiliki kompetensi "kecerdasan kreatif". Hal ini ditandai adanya kemampuan menghubungkan suatu fenomena, fakta, contoh, unsur rupa ke dalam suatu karya dengan komposisi atau tatanan yang baru. Kemampuan menghubungkan ide yang bersumber dari hasil pengamatan obyek alam, obyek budaya, realitas suasana yang ada disuatu waktu dan tempat, fakta yang menarik dari alam sekitar, dari peristiwa, pengalaman, dan imajinasi seseorang. Kecerdasan kreatif dipahami juga sebagai proses berpikir kreatif dengan melihat berbagai sumber/obyek yang beragam untuk diolah menjadi suatu ide baru. Kecerdasan kreatif pada diri seseorang tentunya ada kaitan atau hubungannya dengan keluasan pengetahuan (kognitif) yang dimiliki, kemampuan berpikir kritis, yang dapat mendorong kreatifitas berkarya seni. Menurut (Wiliam, dalam Munandar 1999) dinyatakan ciri-ciri kreatifitas kognitif yaitu (1) keterampilan berpikir lancar (fluency), (2) keterampilan berpkir luwes, fleksibel (flexibility), (3) keterampilan berpikir orisinal (originality), (4) keterampilan memerinci (elaboration), dan (5) keterampilan menilai (evaluation). Selanjutnya mengenai adanya kreativitas pada diri seseorang yang lebih berkaitan dengan aspek afektif (sikap dan perasaan) ciri-cirinya yaitu adanya rasa ingin tahu, berani mengambil resiko akan kegagalan yang dilakukan, ada rasa percaya diri, adanya sifat keterbukan dengan pengalaman baru, dan bisa menghargai kondisi dari karya seni yang ada.

Mengenai kriteria kreativitas dinyatakan bahwa tanpa adanya kejelasan mengenai kreativitas, suatu produk karya diragukan kualitas hasilnya. Kriteria kreativitas berkaitan dengan aspek proses, person, dan produk kreatif. Proses kreatif dari tahapan membuat suatu karya (mulai perencanan, membuat sket yang masih global, menyempurnakan sampai penyelesaian akhir) yang dilakukan sendiri tanpa ada bantuan dari orang lain.. Kreatif "diri seseorang" lebih mengarah pada kondisi kejiwaan (psikologis) yang membentuk kepribadian kreatif. Dalam kaitan ini seseorang mau dan berani menyatakan kejujuran ide/gagasan, dan juga permasalahan yang dirasakan selama proses berkarya seni.

Produk kreatif adalah wujud faktual, kongkrit berupa hasil karya (artefak) yang dapat dinikmati keberadaannya baik dari pengamatan struktur fisik dan struktur isi (maknanya). Dalam kaitan ini kriteria kreatifitas tidak bisa lepas dari kaitan tiga unsur budaya, yaitu (a) ide/gagasan, (b) aktivitas sebagai wujud nyata yang berupa tindakan, dan (c) artefak yang berupa hasil karya/benda. Produk kreatif senirupa akan ditentukan berdasarkan sejumlah aspek rupa (visual) yaitu adanya kesan kebaruan komposisi, orisinal, keindahan, dan bernilai seni (artistik). Secara umum ciri seni kreatif adalah unik, indah, ekspresif, universal dan indiviual. Sebagai karya seni visual menurut 
Jazuli (2008) berfungsi untuk menyampaikan ceritera, memahami ide-ide dan perasaan, untuk menghiasi kehidupan dengan dekorasi tertentu.

Gagasan bagaimana teknik dalam menuntun pengembangan kreativitas keterampilan kreatif, khususnya menganyam sederhana dan mencetak tinggi pada anak-anak SD, menurut satgas abdimas adalah sebagai berikut: a) kegiatan yang dilakukan haruslah disesuaikan dengan kemampuan, kebutuhan dan minat anak (Sumanto. 2006). Contoh dalam kegiatan menganyam peralatan hendaknya dipertimbangan yang mudah dalam penggunaannya. Mengenai bentuk kreasi anyaman yang dibuat hendaknya disesuaikan dengan ide atau kreativitas setiap anak. Bentuk anyaman yang dihasilkan sifatnya untuk lebih mengarahkan anak dalam bereksplorasi keterampilan sesuai langkah anayaaman yang dibuat; b) Berikan kesempatan untuk berekspresi dengan menggunakan berbagai media senirupa, Media/bahan praktek senirupa yang dibutuhkan dan yang disediakan di SD hendaknya disesuaikan dengan keragaman jenis materi seni yang dipraktekkan. Untuk praktek mengamyam sediakan kertas asturo. Dengan mengetahui model karya yang dibuat anak akan bermanfaat dalam memberikan bimbingan proses kerja secara lebih terarah dan bisa memahami jiwa/perasaan yang ada pada diri anak; c) Produk/hasil kreativitas bukanlah tujuan akhir yang terlalu penting, melainkan bagaimana hubungan antara kegiatan yang dilakukan dengan kesenangan pekerjaan yang dilakukan. Dalam hal ini pengalaman berolah senirupa bagi anak SD sebagai dasar untuk menumbuhkembangkan multiple intelegenci akan lebih bermakna. Oleh karena itu penilaian proses kerja merupakan bagian yang tidak terpisahkan dari keseluruhan kegiatan pembelajaran senirupa di SD; d) Berikan motivasi dan rangsangan sebelum memulai kegiatan berkarya, antara lain berkaitan dengan pengalaman dan kemampuan yang dimilikinya. Contoh dengan memberikan penguatan dari kemampuan berkarya yang telah dilakukan, melalui pembahasan proses kerja dan karya yang telah dibuat sehingga anak akan lebih terpacu/bergairah pada waktu memulai mengerjakan latihan yang baru diberikannya.

Luaran yang berkaitan dengan manfaat bagi khalayak sasaran apabila perubahan kondisi terjadi setelah kegiatan ini selesai. Bagi guru SD setelah tujuan kegiatan ini tercapai dapat meningkatkan efektifitas dan kualitas pembelajaran di SD masang- masing, Produkyang dihasilkan bersifat fungsional dan bernilai estetis bisa dimanfaatkan selain di sekolah juga bisa dijadikan benda hias di rumah atau di kantor. Manfaat dari sisi IPTEKS, guru guru SD mendapat pengetahuan dan pengalaman praktis tentang berbagai teori ilmu pengetahuan dan teknologi sederhana tentang pembuatan produk yang bernilai praktis, dan estetis. Teori-teori yang didapat diantaranya pengembangan potensi seni dan motorik halus anak, teori seni dan desain. Teknologi yang didapat meliputi teknik anyaman dasar, anyaman kombinasi, anyaman bentuk khusus, teknik kirigami (menggunting kertas) jadi hiasan, dan lainnya. IPTEKS yang terlibat dipadukan dengan potensi pengetahuan dan pengalaman para guru SD yang sudah mengajar puluhan tahun.

\section{METODE}

Tahap kegiatan yang dilakukan adalah sebagai berikut. (1) Satgas mempelajari terlebih dahulu tentang teknik berkarya kreatif senirupa di SD, Acuannya berkaitan dengan kompetensi dasar dan indikator materi mencetak, dan menganyam. (2) Satgas memperkaya tentang pengetahuan keragaman teknik berkarya kreatif senirupa keterampilan melalui observasi media, alat dan proses pembuatan dari setiap karya senirupa yang akan dilatihkan. (3) Satgas observasi di lingkungan masyarakat sasaran untuk mengidentifikasi berbagai bahan buatan yang sesuai dengan pembuatan karya kreatif senirupa dan pembelajaran serta contoh karya senirupa yang paling efektif dan efisien. (4) Satgas dibantu seorang mahasiswa PGSD angkatan tahun 2017 membuat prototype model contoh karya senirupa keterampilan yang representatif dan memenuhi syarat 
keindahan dan kepraktisan dalam proses pembuatnnya. (5) Guru-guru SD yang menjadi khalayak sasaran diberi pelatihan pembuatan karya senirupa keterampilan sesuai dengan jadwal yang sudah disepakati. (6) Peserta pelatihan dengan bimbingan satgas mempraktekkan membuat karya anyaman model ikan, pita, bintang, burung terbang, keranjang/besek, serta dompet. (7) Peserta pelatihan bersama satgas menyusum rancangan pengembangan materi berkarya kreatif senirupaprakarya untuk pembelajaran di SD sesuai kelas dan alokasi waktu yang direncakanan. Hasil pelatihan berupa produk karya anyaman, serta rancangan materi berkarya senirupa ini dijadikan bahan evaluasi terhadap keberhasilan peningkatan kemampuan guru-guru SD sebagai kelompok sasaran.

Metode pelatihan yang digunakan meliputi ceramah Tanya jawab melalui tayangan powerpoint, demontrasi, praktek membuat karya senirupa keterampilan serta kerja individu. Secara lebih rinci metode pelatihan dijelaskan berikut ini. Ceramah dan Tanya jawab untuk menyampaikan materi pengembangan senirupa dan berkarya kreatif senirupa bagi anak usia SD. Demonstrasi untuk memperagakan tahap-tahap membuat karya anyaman model ikan dari kertas asturo, Pemberian bimbingan praktek berkarya anyaman secara individual dengan memanfaatkan bahan yang telah disediakan oleh satgas, dan menulis rancangan materi berkarya senirupa untuk siswa SD sesuai teknik yang dipilihnya. Melakukan evaluasi dengan mengisi instrumen balikan tentang bentuk pelatihan, materi yang dilatihkan, tingkat kemudahan dan kesulitannya, serta saran dan harapan tindak lanjut dari pelatihan.

\section{HASIL DAN PEMBAHASAN}

Pelaksanaan pelatihan keterampilan membuat anyaman ini merupakan bagian dari Abdimas pelatihan SBdP yang dilaksanakan tanggal 21 dan 22 September 2019, dengan kelompok sasaran 24 guru SD di gugus 1 Kecamatan Ngantang Kabupaten Malang. Dari pelatihan tersebut telah dicapai dua hasil, yaitu hasil non-fisik dan hasil fisik berupa produk karya senirupa.

\section{Hasil Pelatihan Non Fisik}

Khalayak sasaran sebagai peserta kegiatan ini seluruh guru-guru SD kelas rendah (I. II. Dan III) di kecamatan Ngantang yang berasal dari 8 SD, yaitu 6 lembaga satuan pendidikan Sekolah Dasar, yaitu SDN 2 Waturejo (sebagai SD Inti), SDN 1 Waturejo, SDN 3 Waturejo, SDN 1 Banjarejo, SDN 2 Banjarejo, SDN Jombok, dan SDN Mulyorejo.

Pada hari pertama pelatihan (hari Sabtu, 21 September 2019), dimulai pukul 08.10 dilakukan acara pembukaaan bertempat di ruang pertemuan (Aula) SDN 2 Waturejo Ngantang, diawali menyanyikan lagu Indonesia Raya yang dipimpin oleh salah satu peserta pelatihan. Dilanjutkan sambutan Ketua Gugus 1 yang disampaikan oleh Budi Rahayu, S.Pd.SD, dilanjutkan sambutan pengawas pendidikan Gugus 1 yang disampaikan Ibu Dra.Titik Purwanti, M.Pd, dan sambutan Koordinator wilayah dinas pendidikan Kecamatan Ngantang, serta sekaligus membuka pelatihan yang disampaikan oleh Bapak Abdul Manaf, S.Pd. MM.

Dari sambutan pengawas dan koordinator wilayah dinas pendidikan Kecamatan Ngantang pada intinya mengucapkan terima kasih kepada Satgas Abdimas dari Prodi PGSD Jurusan KSDP FIP UM yang telah memberikan pelatihan SBdP khususnya materi berkarya senirupa-prakarya yang sangat dibutuhkan para guru SD yang ada di Kecamatan Ngantang. Juga berharap kedepannya para dosen UM masih ada yang melaksanakan pelatihan sejenis di wilayah Ngantang dengan kelompok sasaran lainnya. Koordinator wilayah dinas pendidikan juga mengajak bagi peserta untuk dapat mengikutinya dengan sunguh-sunguh seluruh materi yang dilatihkan. Selanjutnya hasil pelatihan ini dapat diterapkan di sekolahnya masing-masing untuk meningkatkan 
kualitas pembelajarannya. Acara selanjutnya adalah sambutan satgas Abdimas UM yang disampaikan oleh Drs. Sumanto, M.Pd, dan cara pembukaan diakhiri dengan pembacaan do'a.

Acara inti pelatihan pada pukul 8.50. dengan memberikan penjelasan teknis (Gambar 1.) berkaitan dengan tujuan pelatihan, kegiatan praktek membuat anyaman dan mencetak tinggi yang akan dilakukan selama dua hari, dan hasil akhir berupa produk karya senirupa yang diharapkan. Pada pukul 09.10 satgas menberikan paparan materi berkarya kreatif senirupa dwimatra dan trimatra dengan memanfaatkan ketersediaan LCD ada di ruang aula tempat pelatihan. Secara teknik satgas juga dibantu alumni PGSD UM yang sudah mengajar di SDN 2 Waturejo. Kemudian diteruskan dengan penjelasan dan peragaan cara membuat model-model karya kerajinan anyaman dari bahan kertas asturo.

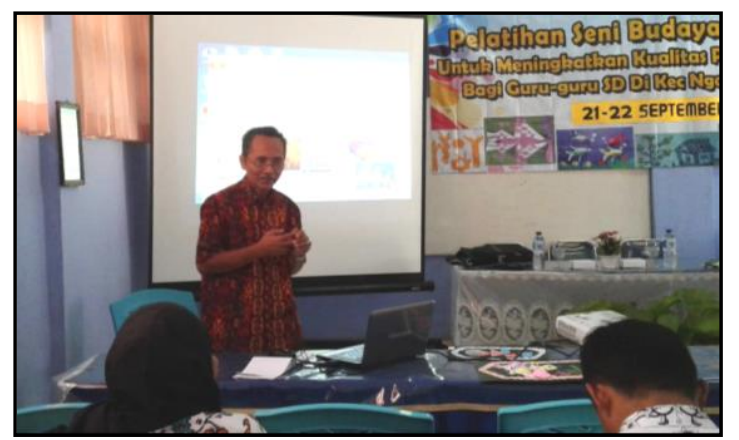

Gambar 1. Satgas memberikan penjelasaan teknik membuat karya anyaman

Pelatihan yang pertama yaitu membuat kreasi anyaman model Ikan 1 dan Model Ikan 2 dari kertas Asturo. Pada saat peserta pelatihan diberikan praktek berkarya kerajinan anyaman model Ikan tersebut, secara bergantian diberikan bimbingan langkah-langkah menganyam oleh Satgas Abdimas. Dengan menggunakan kertas Asturo ukuran lebar $5 \mathrm{~cm}$ dan panjang $35 \mathrm{~cm}$ yang telah dipersiapkan oleh satgas, terlihat aktifitas para peserta secara individu dengan sangat aktif membuat anyaman model ikan (Gambar 2.). Selama proses mengamyam masih terlihat adanya kesulitan menganyam dengan cermat, rapi dari beberapa peserta, sehingga masih diperlukan bimbingan secara individu.
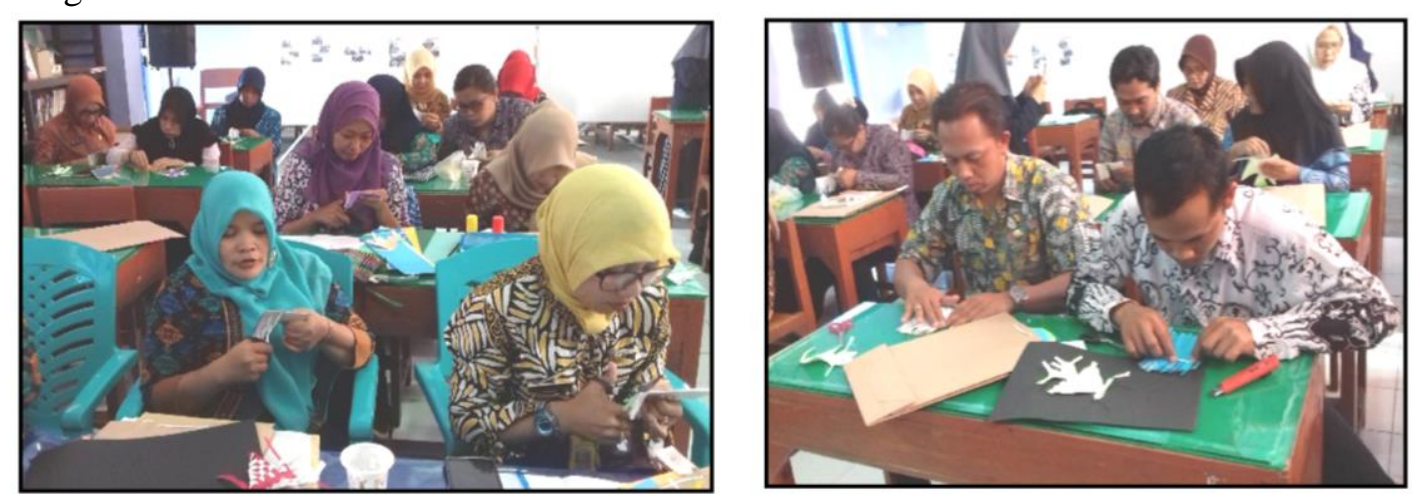

\section{Gambar 2. Peserta Berlatih membuat Anyaman Bentuk Ikan}

Praktek kerajinan anyaman yang kedua, yaitu membuat anyaman Pita yang dibentuk Pigura. Pada latihan yang kedua ini juga diberikan peragaan dan bimbingan seara klasikal dan individu pada tahapan melipat dan menganyam pita kertas asturo untuk dibentuk pigura. yang juga dibantu oleh mahasiswa PGSD (Gambar 3.).

Hasil anyaman pigura akan digunakan untuk menempelkan karya anyaman model ikan yang telah dibuat sebelumnya. Selama proses membuat anyaman bentuk pigura membutuhkan waktu yang lebih lama. Tingkat kesulitan peserta pelatihan yaitu pada tahapan membuat anyaman 
membentuk sudut-sudut dibagian kanan dan kiri, serta pada lipatan (anyaman) di belokan (tikungan) agar bisa membentuk bidang pigura.

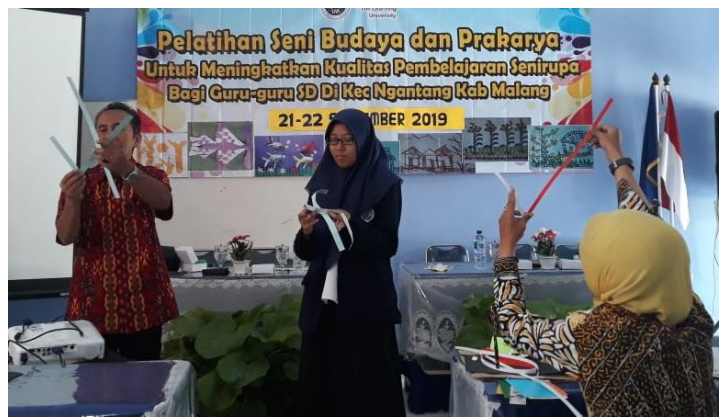

\section{Gambar 3. Peragaan membuat anyaman pita, yang juga dibatu oleh mahasiswa PGSD}

Pada hari kedua pelatihan (Minggu, 22 September 2019) mulai pukul 08.00 dimulai dengan praktek anyaman keempat, yaitu Burung Terbang. Setelah diberikan penjelasan dan peragaan membuat anyaman bentuk Burung Terbang selanjutnya setiap peserta mulai mempraktekkannya. Dengan menggunakan 2 potong kertas Asturo ukuran $4 \mathrm{~cm}$ x $45 \mathrm{~cm}$ dibentuk sayap burung pada salah satu sisi panjangnya kertas sekitar 6-7 cm. Kemudian lembaran kertas dipotong memanjang masing-masing menjadi 4 bagian yang sama. Baru setelah itu dibentuk posisi badan burung dan dianyam ujung-ujung potongan kertasnya. Suasana keseriusan proses berlatih keterampilan anyaman Burung Terbang tersebut terlihat pada gambar 4.

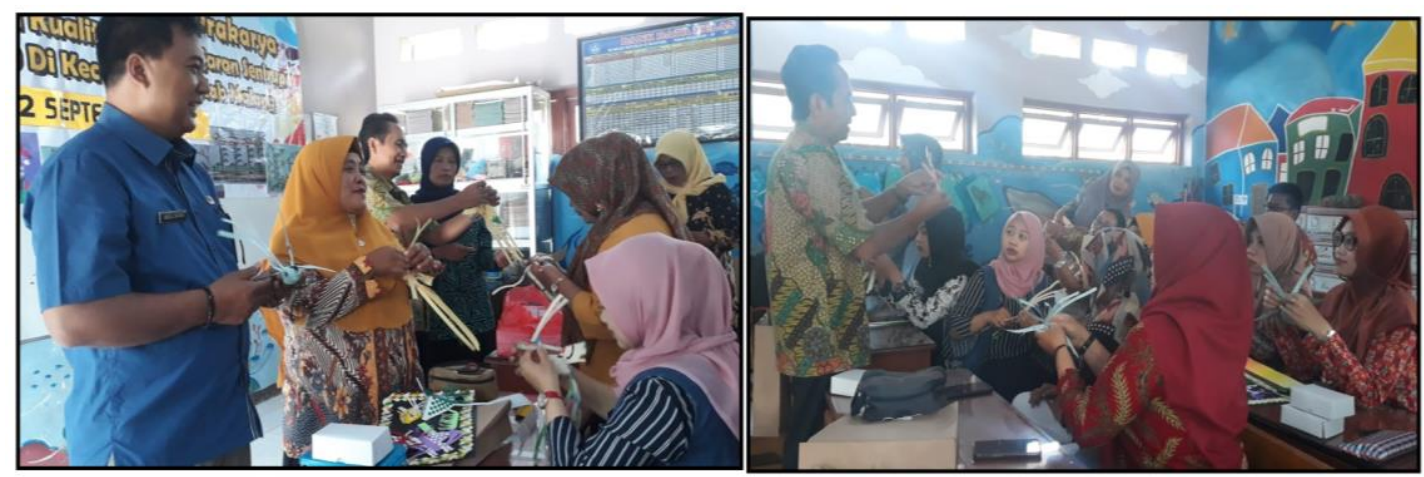

\section{Gambar 4. Peserta berlatih membuat anyaman Model Burung Terbang}

Selanjutnya materi pelatihan yang kelima yaitu kegiatan berlatih membuat anyaman bentuk Keranjang/Besek, Proses kegiatan pelatihan membuat anyaman ini setiap peserta menyiapkan bahan 20 potong kertas Asturo (2 macam warna) ukuran lebar $1 \mathrm{~cm}$ dan panjang $35 \mathrm{~cm}$. Dengan menggunakan potongan kertas tersebut selanjutnya dibentuk anyaman ditengah panjangnya kertas (Gambar 5).

Praktek anyaman yang keenam yaitu membuat anyaman Dompet/Tas. Bahan yang diperlukan sama seperti anyaman Besek. Dari 20 potong kertas dianyam di tengah posisi miring (diagonal) membentuk bidang belah ketupat. Setelah dirapatkan kemudian dilem pada keempat pojok pertemuan kertas dan selanjutnya dilipat di tengah menjadi bidang segitiga. Tahapan berikutnya menganyam ujung-ujung kertas di samping kanan dan kiri membentuk badan dompet. Aktivitas peserta mempraktekkan anyaman model Dompet (Gambar 6).

Diakhir pelatihan materi kerajinan anyaman, peserta diberikan kegiatan praktek anyaman yang ketujuh, yaitu anyaman Bentuk Bintang. Dengan menggunakan empat potong kertas Asturo, ukuran lebar $2 \mathrm{~cm}$ dan panjang $40 \mathrm{~cm}$ dapat dibuat kreasi anyaman. Setelah diberikan penjelasan 
dan peragaan langkah-langkah membuat anyaman bentuk bintang semua peserta pelatihan langsung mempraktekkannya dengan mendapatkan bimbingan dari satgas dengan dibantu alumni dan mahasiswa PGSD.

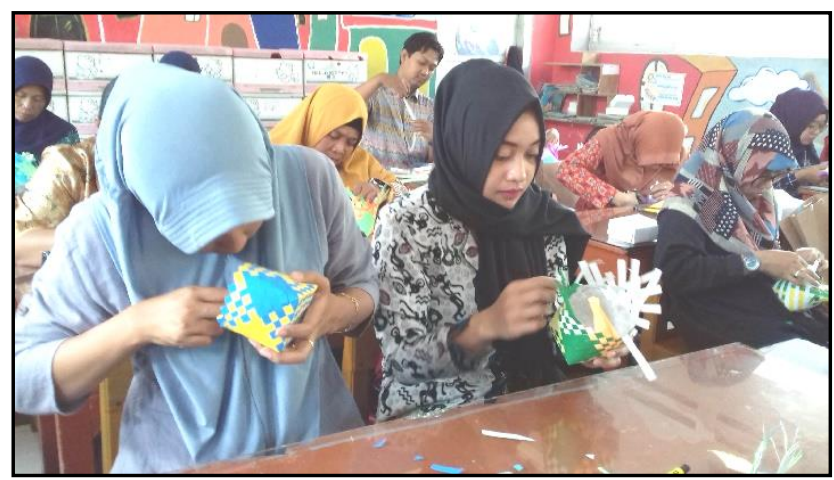

Gambar 5. Peserta membuat anyaman Keranjang/Besek
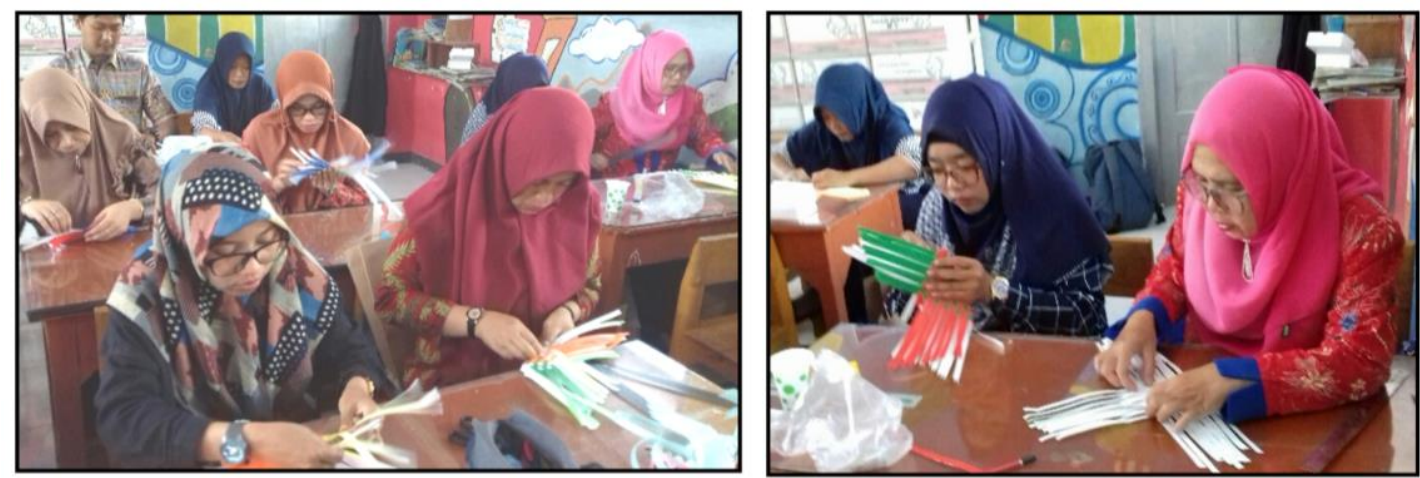

Gambar 6. Peserta pelatihan berlatih membuat anyaman Dompet
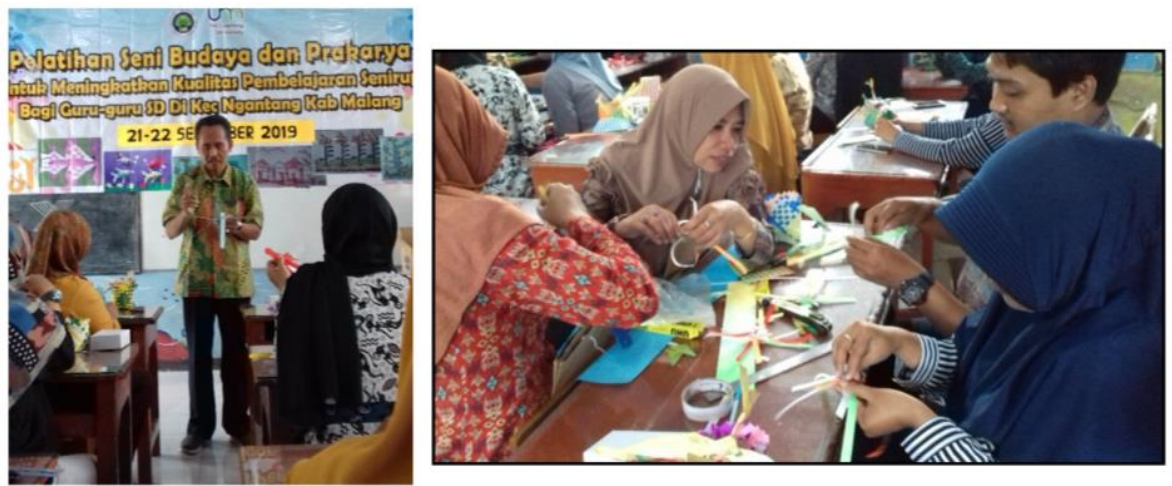

\section{Gambar 7. Peragaan dan peserta praktek membuat anyaman model bintang}

\section{Hasil Fisik}

Hasil fisik berupa produk anyaman yang dibuat oleh setiap peserta diberikan contoh yakni; a) hasil membuat anyaman bentuk ikan yang dibuat dari kertas asturo dan anyaman pita bentuk pigura oleh peserta; b) hasil berlatih membuat anyaman bentuk burung terbang yang telah dibuat dari kertas asturo oleh setiap peserta; c) hasil berlatih membuat anyaman bentuk Bintang yang telah dibuat dari kertas asturo oleh setiap peserta dicontohkan pada foto 13; d) hasil berlatih membuat anyaman bentuk Keranjang/Besek dan Dompet yang telah dibuat dari kertas asturo oleh setiap peserta. 


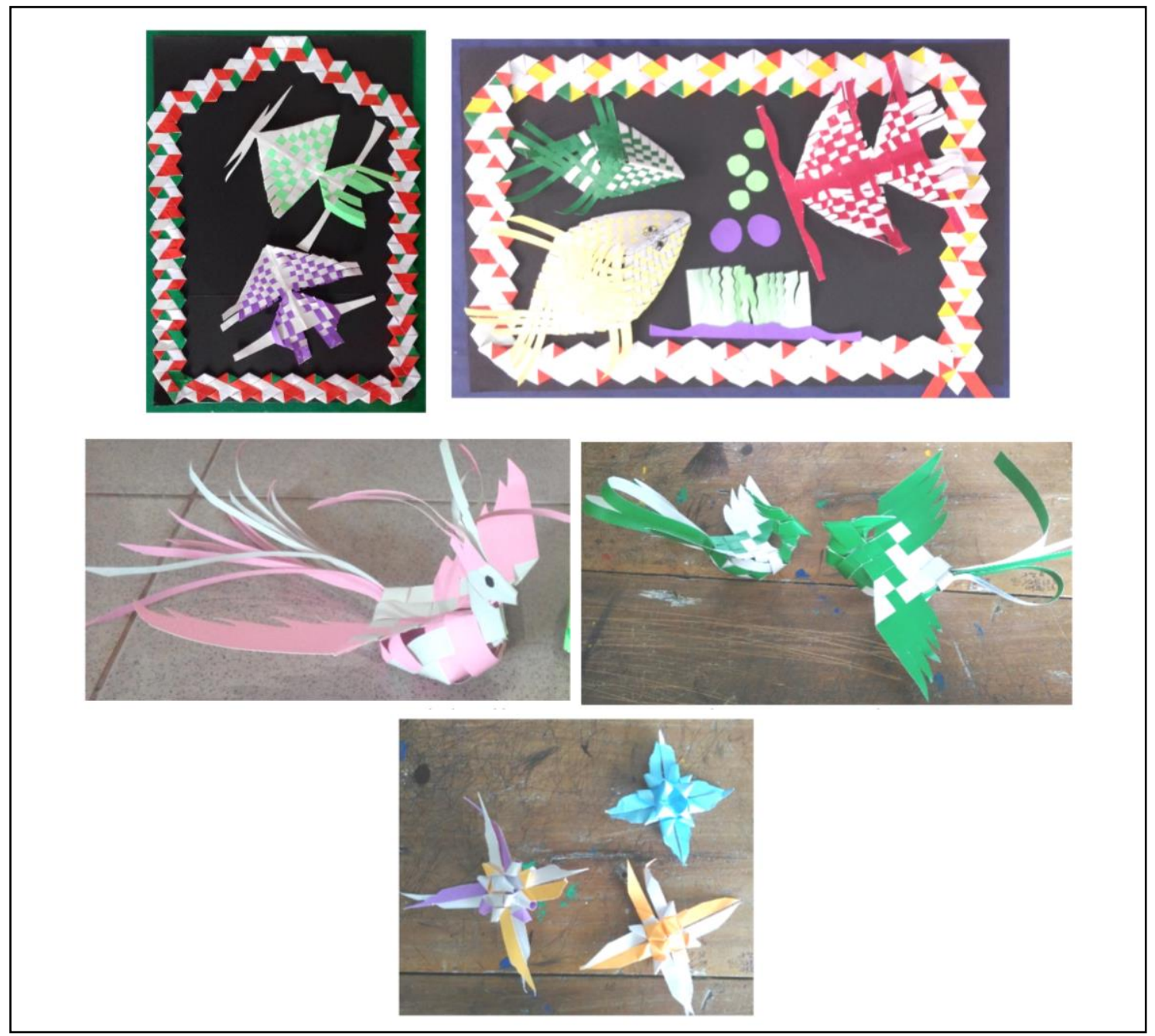

Gambar 8. Hasil karya membuat hiasan dari anyaman

\section{Balikan dari peserta pelatihan SBdP untuk meningkatkan pembelajaran senirupa bagi guru SD di gugus 1 Kecamatan Malang}

Dari hasil observasi selama kegiatan pelatihan terstruktur yang bertempat di SDN 2 Waturejo Ngantang pada tanggal 21 dan 22 September 2019, dan balikan dari peserta pelatihan menunjukkan bahwa selama proses pelatihan peserta sangat bersemangat, serius dan antusias mengikuti seluruh kegiatan pelatihan. Khusus mengenai kehadiran peserta selama 2 hari pelatihan mencapai $100 \%$. Dari 24 guru SD yang diundang, telah hadir sebanyak 24 orang guru berasal dari 8 SDN se gugus 1 kecamatan Ngantang. Selama waktu pelatihan peserta aktif mengikuti sajian materi, bertanya dan mengerjakan latihan-latihan praktek pembuatan 6 (enam) macam bentuk anyaman dari bahan kertas.

Mengenai kehadiran peserta selama 2 hari pelatihan mencapai 96\%. Telah hadir sebanyak 24 orang guru berasal dari 8 SDN di gugus 1 kecamatan Malang. Selama waktu pelatihan peserta aktif mengikuti sajian materi, bertanya dan mengerjakan latihan-latihan praktek pembuatan 6 macam bentuk anyaman dari bahan kertas dan lainnya. Peserta pelatihan setelah mengikuti semua praktek membuat anyaman dan mencetak tinggi terlihat telah memahami pengetahuan dan keterampilan senirupa-prakarya yang selama ini belum pernah dilatihkan sebagai materi pembelajaran SBdP di SD. Bertambahnya pengetahuan dan keterampilan kerajinan anyaman di SD bagi peserta pelatihan dapat digunakan sebagai dasar pengembangan kegiatan perencanaan dan 
pelaksanaan pembelajaran di SD. Setelah pelatihan terjadi perubahan pandangan dan perilaku ke arah positif terhadap pengembangan materi, bahan, media dan cara pembelajaran yang dapat memanfaatkan bahan buatan yang tersedia dilingkungan sekitar. Perilaku adalah perbuatan atau tindakan seseorang sebagai wujud dari penghayatan rasa dan kesan (Hidayah. 1988). Dalam proses berkarya perwujudan sikap dan perilaku ini dapat dianggap sebagai suatu kecenderungan individu untuk bertindak dengan cara-cara tertentu pada saat melakukan aktivitas berkarya.

Berdasarkan hasil yang dicapai selama proses pelatihan dan setelah pelatihan yang meliputi keaktifan, antusiasme, dan kreativitas dalam menghasilkan kreasi karya beberapa model anyaman, maka dapat dinyatakan bahwa kegiatan pelatihan yang telah dilakukan berhasil sesuai kontrak yang direncanakan. Dapat dikemukakan antara kondisi sebelum dan sesudah diadakknya kegiatan pelatihan seni keterampilan adalah sebagai berikut. Berdasarkan balikan melalui instrumen yang diberikan kepada peseta pelatihan di akhir kegiatan diperoleh hasil baik mengenai kesesuaian materi, kejelasan sajian, kebermanfaatan, tingkat kemudahan dan kesulitan dipaparkan sebagai berikut.

Berdasarkan hasil balikan menunjukkan bahwa dari keseluruhan peserta (32) yang mengisi balikan menyatakan bahwa: (1) materi pelatihan sangat sesuai $(82,60 \%)$, dan $(17.40 \%)$ menyatakan sesuai, (2) mengenai kejelasan sajian materi dan pemberian contoh cara pembuatan karya senirupa-prakarya menurut sebagian besar peserta pelatihan $(60.87 \%)$ sangat jelas, dan (39.130\%) peserta menyatakan jelas, (3) kebermanfaatan dari materi praktek berkarya senirupaprakarya yang telah dilatihkan sebagian besar peserta menyatakan sangat bermanfaat $(78.26 \%)$, dan bermanfaat $(21.74 \%)$. Pemanfaatan teknik-teknik kerajinan dalam pembelajaran di SD dapat diwujudkan melalui pendekatan saintifik dari bahan alam dan buatan yang ada dilingkungan sekitar (Sumanto. 2017:37).

Mengenai tingkat kesulitan-kemudahan dalam keseluruhan materi senirupa-prakarya yang dilatihkan peserta menyatakan mudah (39.13\%), dan cukup sulit dinyatakan oleh (60.13\%) peserta pelatihan. Tingkat kesulitan dan kemudahan dari setiap materi praktek anyaman yang dinyatakan oleh peserta pelatihan dipaparkan sebagai berikut. Tingkat kesulitan dan kemudahan materi praktek kerajinan anyaman dari bahan kertas menunjukkan bahwa: (1) pada praktek anyaman bentuk Ikan 1 sebagian besar (12) peserta pelatihan menyatakan sangat mudah (52.18\%), dan 47.82\% menyatakan mudah. (2) Tingkat kesulitan-kemudahan dalam pembuatan anyaman bentuk Ikan model 2 dinyatakan sangat mudah oleh 1 orang peserta (4.34\%), dan 14 peserta pelatihan yaitu $(65.22 \%)$ menyatakan mudah, serta (34.79\%) cukup sulit. (3) Tingkat kesulitan-kemudahan dalam pembuatan anyaman Pita yang dibentuk Pigura dinyatakan oleh sebagian besar peserta pelatihan $(82.60 \%)$ adalah cukup sulit, $(8.20 \%)$ menyatakan sangat sulit, dan $(8.20 \%)$ menyatakan mudah. (4) Tingkat kesulitan-kemudahan dalam pembuatan anyaman bentuk Burung Terbang dinyatakan oleh peserta pelatihan (69.56\%) cukup sulit, dan (30.44\%) menyatakan mudah, dan dua orang peserta (8.68\%) menyatakan sangat sulit . (5) Tingkat kesulitan-kemudahan dalam pembuatan anyaman bentuk Bintang dinyatakan oleh sebagian peserta pelatihan (65.22\%) yaitu cukup sulit, (4.34\%) menyatakan sangat sulit, dan (30.44\%) menyatakan mudah. (6) Tingkat kesulitan-kemudahan dalam pembuatan anyaman bentuk Kotak dinyatakan oleh sebagian besar peserta pelatihan (78.26\%) cukup sulit, dan (21.74\%) menyatakan mudah.

Menurut peserta pelatihan yang masih merasakan adanya kesulitan dalam pembuatan setiap model atau bentuk anyaman yang berkaitan dengan suasana dan obyek gagasannya. Adanya kontak dengan suasana dan obyek yang ada dilingkungan akan melahirkan adanya ide atau gagasan awal yang akan diungkapkan ke dalam karya senirupa (Sumanto. 2014). Pada pembuatan anyaman bentuk Ikan 1 masih ada sedikit kesulitan yaitu ditahap awal menganyam silang 
membentuk badan pesawat. Pada pembuatan anyaman bentuk Ikan 2. kesulitannya yaitu kerapian dalam memotong, saat menyatukan bagian yang telah dianyam (langkah pertama), kesulitan dalam memotong kertas, kertas mudak sobek, kadang jumbuh langkah anyaman yang dibuat, melipat/menekuk dua sisi menganyamnya. Pada pembuatan anyaman bentuk Pigura. kesulitannya yaitu belokan langkah-langkah dan untuk membelokan langkah anyaman, batas belokan, bagian sudut anyaman, kertas mudah robek, menyimetriskan bentuk sampai tahapan menyambung ke dua ujung anyaman (anyaman langkah awal dengan anyaman langkah akhir). Pada pembuatan anyaman bentuk Burung Terbang. kesulitannya yaitu badan, kepala, sayap, paruh, anyaman belakang, bentuk tubuh, menentukan bentuk leher, sering dompo dan kurang rapi hasil anyamannya. Pada pembuatan anyaman bentuk Bintang. kesulitannya yaitu pembentukan bentuk binatang, menentukan belokan, membentuk pita, membentuk bagian atas, menentukan lekukan, dan membentuk ujung binatang. Pada pembuatan anyaman bentuk Kotak. kesulitannya yaitu menganyam setiap dudut kotak sampai membentuk badan kotak/besek, kemudian melanjutkan menganyam ujung/pita kertas, dan terakhir mengakiti lipatan kunci ke bagian dalam badan anyaman.

Saran pelatihan dari peserta pelatihan yaitu sudah bagus, penambahan pelatihan, waktu pelatihan perlu ditambah dan berkelanjutan, Semua peserta masih membutuhkan adanya bimbingan secara individu dalam setiap tahapan dari karya senirupa yang dilatihkan. Pelatihan lebih dari 2 hari, lebih mendetail penjelasannya, waktu pelatihan terlalu cepat. Perlu dikembangkan dengan keterampilan yang lain dengan model yang variatif. Semua peserta masih berharap ada kegiatan pelatihan lagi (pelatihan SBdP) lanjutan, Dicontohkan materi berkarya kreatif merangkai-meronce, melukis, membuat hiasan dari bahan alam dan materi seni yang lainnya.

\section{SIMPULAN}

Berdasarkan hasil kegiatan dan pembahasan baik yang bersifat fisik maupun non fisik yang berupa adanya perubahan kondisi pengetahuan, keterampilan, maupun sikap yang tampak pada peserta pelatihan, maka dapat disimpulkan sebagai berikut.

Pertama, kegiatan pengabdian kepada masyarakat berupa pelatihan senirupa-prakarya bagi guru-guru SD di gugus 1 Kecamatan Ngantang ini bersifat Dikmas (pendidikan masyarakat). Lingkup materi pelatihan berupa bimbingan keterampilan berkarya kreatif: berkarya menganyam bentuk ikan model 1, ikan model 2, anyaman pita dibentuk pigura, burung terbang, bintang, dan anyaman kokak/besek, serta anyaman dompet dengan menggunakan bahan kertas asturo. Dari kegiatan pelatihan senirupa-prakarya untuk meningkatkan kualitas pembelajaran senirupa bagi guru di SD di gugus 1 kecamatan Ngantang telah berhasil dengan baik.

Kedua, secara khusus, keberhasilan kegiatan ini meliputi: (a) guru SD peserta pelatihan telah dapat menjelaskan konsep pengembangan materi berkarya kreatif senirupa khususnya menganyam bahan kertas asturo, dan (b) guru SD peserta pelatihan telah terampil melakukan teknik menganyam sesuai bahan yang digunakan dan kreasi yang dibuat, (c) guru SD peserta pelatihan telah mampu membuat karya anyaman bentuk ikan model 1, ikan model 2, anyaman pita, model anyaman burung terbang, anyaman bentuk bintang, dan anyaman keranjang/besek, serta anyaman dompet.

Kegiatan pengabdian berupa pelatihan seni keterampilan SD bagi guru-guru sebaiknya dilaksanakan secara berkesinambungan, dan sebaiknya ketika libur sekolah supaya tidak mengganggu tugas mengajarnya. 


\section{DAFTAR RUJUKAN}

Hidayah, Nur. (1988). Perilaku Bermasalah Anak Usia SD, Jurnal Sekolah Dasar. Malang: PGSD FIP UM.

Jazuli, M. (2008). Paradikma Kontekstual Pendidikan Seni. Surabaya: Unesa Press.

Munandar, SC. Utami. (1999). Kreativitas dan Keberbakatan (Strategi Mewujudkan Potensi dan Bakat). Jakarta: Gramedia Pustaka Utama.

Pamadhi, Hajar, dkk. (2008). Seni Keterampilan Anak. Jakarta: Penerbit UT.

Sumanto. (2014). Pendidikan Senirupa di SD. Malang: Percetakan Rosindo.

Sumanto. (2006). Pengembangan Sumber Belajar Pendidikan Seni Rupa SD/MI. Jurnal Sekolah Dasar Th.15 No.2 . Malang: PGSD FIP UM.

Sumanto. (2017). Ragam Teknik dan Bahan Kerajinan Tangan sebagai Sumber Belajar Seni Budaya dan Prakarya Sekolah Dasar. Jurnal Sekolah Dasar tahun 26. Nomor 1, Mei 2017, hal.37. Malang: Jurusam KSDP FIP UM. 